УДК 657.1 .012

\author{
Іванченкова Л.В. \\ кандидат економічних наук, доцент \\ E-mail: I.ivanchenkova@mail.ru \\ Ткачук Г.О. \\ кандидат економічних наук, доцент \\ E-mail: talla2007@ukr.net \\ Скляр Л.Б. \\ кандидат економічних наук, доцент \\ кафедра обліку та аудиту \\ Одеська національна академія харчових технологій \\ вул. Канатна, 112, м. Одеса, Україна, 65039 \\ E-mail: sklyarl@mail.ru
}

\title{
ЕКСПЕРТНЕ ПІДТВЕРДЖЕННЯ ОБЛІКОВО-АНАЛІТИЧНОЇ ІНФОРМАЦІї
}

В даній статті виділено напрями організації експертних досліджень на підприємстві. Узагальнено інформацію щодо видів експертиз для ідентифікації фінансово-економічних правопорушень 3 визначенням очікуваного результату від експертизи. Проведена систематизація методичних прийомів, за допомогою яких встановлюються докази протиправних дій в економічній сфері. Визначено основні функції експертної служби підприємства.

Ключові слова: обліково-аналітична інформація, експертиза, судово-бухгалтерська експертиза, методичні прийоми експертизи, фрінансові правопорушення.

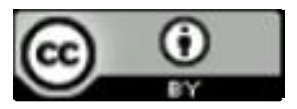

This work is licensed under a Creative Commons Attribution 4.0 International License http://creativecommons.org/licenses/by/4.0/

Постановка проблеми та їі зв'язок з важливими науковими та практичними завданнями. Основне завдання внутрішньої та зовнішньої фінансової інформації щодо діяльності підприємства полягає в наданні ії користувачам своєчасних та достовірних даних для прийняття відповідних рішень. Оскільки базовим джерелом фінансової інформації $\epsilon$ первинні, зведені та звітні ресурси обліково-аналітичної системи, якість обліково-аналітичних даних суттєво впливає на конструктивність оперативних управлінських рішень.

Обліково-аналітична інформація повинна бути захищеною від ймовірних похибок та викривлень. В цьому аспекті гарантом достовірності виступають заходи внутрішнього та зовнішнього контролю, в т.ч. експертне підтвердження інформації.

Аналіз останніх публікацій по проблемі. Проблематика організації, проведення та реалізації результатів експертних досліджень представлена в сучасному науковому полі працями Ф.Ф. Бутинця, C.А. Звягіна, Н.А. Остап'юк, І.А. Панченко, Н.І.Клименко, І.В. Сауткіна, Є.Р. Россинської, М.Т. Білухи, Є.С. Дубоносова, В.В. Шадріна, В.С. Рудницького, Р.Ф. Бруханського та інших.

Нажаль в більшій мірі висвітленню підлягають питання, які стосуються судово-бухгалтерської експертизи в межах розгляду судових справ щодо фінансових правопорушень. Однак у доказах щодо достовірності інформації мають потребу не тільки органи дізнання, слідства, прокуратури або суду, а й інші користувачі інформації, в. т.ч. засновники підприємства, зокрема його управлінський персонал.

Таким чином, питання застосування висновків незалежних спеціалістів (експертів) 3 метою реалізації завдань системи внутрішнього контролю щодо забезпечення достовірності інформації $є$ актуальним питанням та потребує додаткового вивчення.

Формулювання цілей дослідження. В даній статті вирішуються наступні завдання: здійснити узагальнення інформації щодо видів експертиз для ідентифікації фінансово-економічних правопорушень; провести систематизацію методичних прийомів документального дослідження облікової інформації 3 визначенням змісту процедур; виділити основні функції експертної служби підприємства.

Виклад основних результатів та їх обгрунтування. Підсистема внутрішнього контролю обліково-аналітичної системи підприємства включає такі складові як тестування системи внутрішнього контролю, моніторинг та методичні прийоми та процедури внутрішнього контролю. До складу останнього включено документальний контроль, фактичний контроль та експертизу [1].

Основна мета проведення різного виду експертиз на підприємстві пов'язана із необхідністю підтвердження вже сформованих даних щодо різних 
аспектів діяльності. На підприємствах харчової промисловості потреба у проведенні експертних досліджень виникає у випадках, якщо з'являються сумніви щодо обліково-аналітичної інформації, що дозволяє виділити окремі напрями проведення експертиз, в т.ч. внутрішніх [2]:

- обсягів виконаних робіт (в т.ч. будівельномонтажних та ремонтних);

- законності застосування норм витрат сировини та матеріалів;

- наявності залишків матеріалів, напівфабрикатів, готової продукції, коли у зв'язку із специфікою зберігання методи зважування, підрахування та обміру використати неможливо (наприклад, для визначення кількості спирту, вина, виноматеріалу, зерна тощо);

- ідентифікації фінансово-економічних правопорушень (злочинів), вчинених персоналом підприємства.

У вищевказаних випадках використання результатів досліджень, проведених внутрішніми спеціалістами є менш недоцільним, оскільки такий підхід не забезпечує принципу незалежності висновків.

Експертні дослідження виконуються як запрошеними спеціалістами необхідного профілю, так i експертами 3 відповідним рівнем сертифікації. Останні обов’язково залучаються в межах проведення судових експертиз.

Згідно діючого законодавства судова експертиза $\epsilon$ самостійною процесуальною формою отримання і перевірки (уточнення) наявних речових доказів і саме тому відрізняється від експертиз, що здійснюються в інших сферах діяльності, за такими ознакам: отримання спеціальних процесуальних норм, що визначають права та обов'язки експерта і суб'єкта, яким призначено експертизу; використання спеціальних правил підготовки матеріалів для експертизи, iіi призначення і проведення; провадження дослідження, яке грунтується на використанні спеціальних знань із різних галузей народного господарства; надання висновків, що мають силу джерела доказів [3].
Найбільш цікавими для експертного підтвердження фінансово-економічної інформації $є$ [4]:

- почеркознавча експертиза, технічна експертиза документів (класифікаційна група - криміналістична експертиза);

- будівельно-технічна експертиза; інженерноекологічна експертиза; комп'ютерно-технічна експертиза (класифікаційна група - інженерно-технічна експертиза);

- експертиза бухгалтерського та податкового обліку (судово-бухгалтерська); фінансовогосподарської діяльності; фінансово-кредитних операцій (класифікаційна група - економічна експертиза)

- експертиза комерційних (фірмових) найменувань, торговельних марок (знаків для товарів $\mathrm{i}$ послуг); експертиза комерційної таємниці (ноу-хау) і раціоналізаторських пропозицій (класифікаційна група - експертиза у сфері інтелектуальної власності);

- машин, обладнання, сировини та товарів народного споживання; (класифікаційна група - товарознавча експертиза).

Вищевказані види судових експертиз можна проводити на підприємстві для запобігання фінансовим зловживанням та викривленню облікової інформації.

Судово-бухгалтерська експертиза (СБЕ) $\epsilon$ одним із найпоширеніших видів судових експертиз. Необхідність у СБЕ виникає під час розслідування i судового розгляду цивільних справ про привласнення майна, посадові (службові) злочини, а також відносно цивільних справ, коли необхідно проаналізувати дані про фінансово-господарські операції, що відображені в обліку.

У випадках фальсифікації господарських операцій та фінансових результатів, підробки документів та крадіжки товарно-матеріальних цінностей та грошових коштів управлінський персонал підприємства може також ініціювати проведення наступних видів експертиз, що допоможе ідентифікувати фінансово-економічні правопорушення (табл. 1).

Таблиця 1

Види експертиз для ідентифікації фінансово-економічних правопорушень*

\begin{tabular}{|l|l|l|}
\hline \multirow{1}{*}{$\begin{array}{c}\text { Економічні } \\
\text { правопорушення }\end{array}$} & \multicolumn{1}{|c|}{ Види експертиз } & \multicolumn{1}{c|}{ Очікуваний результат } \\
\hline \multirow{4}{*}{$\begin{array}{l}\text { Фальсифікація } \\
\text { (підробка) }\end{array}$} & Експертиза документів & Підтвердження наявності обов'язкових реквізитів \\
\cline { 2 - 3 } & Почеркознавча експертиза & Підтвердження достовірності підпису посадових осіб \\
\cline { 2 - 3 } & Технічна експертиза & Підтвердження доброякісності документів \\
\cline { 2 - 3 } & $\begin{array}{l}\text { Комп’ютерно-технічна } \\
\text { експертиза }\end{array}$ & Підтвердження дати створення документів \\
\hline \multirow{4}{*}{$\begin{array}{l}\text { Фальсифікація } \\
\text { господарських }\end{array}$} & Товарознавча експертиза & Підтвердження кількості, якості та асортименту товарів \\
\cline { 2 - 3 } & Будівельна експертиза & Підтвердження обсягу будівельно-монтажних робіт \\
\cline { 2 - 3 } & Технологічна експертиза & Підтвердження результатів лабораторних аналізів \\
\cline { 2 - 3 } & Експертиза документів & Документальне підтвердження облікових операцій \\
\cline { 2 - 3 } & Юридична експертиза & Підтвердження законності облікових операцій \\
\hline
\end{tabular}


Продовження табл. 1

\begin{tabular}{|c|c|c|}
\hline \multirow{4}{*}{$\begin{array}{l}\text { Фальсифікація } \\
\text { фінансового } \\
\text { результату } \\
\text { (приховування до- } \\
\text { ходів, завищення } \\
\text { витрат) }\end{array}$} & Товарознавча експертиза & Підтвердження кількості, якості та асортименту товарів \\
\hline & Експертиза документів & Документальне підтвердження вартості доходів та витрат \\
\hline & Будівельна експертиза & $\begin{array}{l}\text { Підтвердження фактів завищення обсягу будівельно- } \\
\text { монтажних робіт, суми нарахованої заробітної плати за } \\
\text { затвердженими кошторисами та актами виконаних робіт }\end{array}$ \\
\hline & Технологічна експертиза & $\begin{array}{l}\text { Підтвердження достовірності норм витрат виробничих } \\
\text { запасів на виробництво продукції }\end{array}$ \\
\hline \multirow{4}{*}{$\begin{array}{l}\text { Крадіжка товарно- } \\
\text { матеріальних } \\
\text { цінностей та } \\
\text { грошових коштів }\end{array}$} & Експертиза документів & Документальне підтвердження суми матеріальної шкоди \\
\hline & Юридична експертиза & $\begin{array}{l}\text { Визначення кола відповідальних осіб та ймовірного сту- } \\
\text { пеня їх відповідальності }\end{array}$ \\
\hline & Технологічна експертиза & $\begin{array}{l}\text { Підтвердження залишків ТМЦ у випадках, коли у зв’язку } \\
\text { iз специфікою зберігання класичні методи їх визначення } \\
\text { застосувати неможливо (обсяги зерна, спирту, виномате- } \\
\text { ріалів тощо) }\end{array}$ \\
\hline & $\begin{array}{l}\text { Судово-бухгалтерська } \\
\text { експертиза }\end{array}$ & $\begin{array}{l}\text { Підтвердження суми матеріальної шкоди та визначення } \\
\text { кола відповідальних осіб у цивільній або карній справі }\end{array}$ \\
\hline
\end{tabular}

*Авторська розробка

В табл.2 систематизовані методичні прийоми для

встановлення протиправних фінансово-економічних дій.

Таблиця 2

Методичні прийоми, за допомогою яких встановлюються докази протиправних дій в економічній сфері *

\begin{tabular}{|c|c|c|c|}
\hline Прийоми & Види методичних прийомів & \multicolumn{2}{|l|}{ Завдання } \\
\hline \multirow{3}{*}{$\begin{array}{l}\text { Розрахунково- } \\
\text { аналітичні }\end{array}$} & економічний аналіз & \multirow{3}{*}{\multicolumn{2}{|c|}{$\begin{array}{l}\text { Виявлені негативні тенденції і відхилення від } \\
\text { нормативів лише вказують напрямок прове- } \\
\text { дення більш докладного дослідження }\end{array}$}} \\
\hline & статистичні розрахунки & & \\
\hline & економіко-математичні методи & & \\
\hline \multirow{8}{*}{ Документальні } & \multicolumn{2}{|l|}{ формальна й арифметична перевірки } & \multirow{8}{*}{ 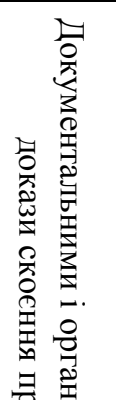 } \\
\hline & \multicolumn{2}{|c|}{ нормативно-правова оцінка відображених у документах господарських операцій } & \\
\hline & \multicolumn{2}{|c|}{$\begin{array}{l}\text { логічний контроль об’єктивної можливості виконання документально оформле- } \\
\text { них господарських операцій }\end{array}$} & \\
\hline & \multicolumn{2}{|c|}{ цілковите і нецілковите (у т.ч. вибіркове) спостереження } & \\
\hline & \multicolumn{2}{|c|}{ дослідження окремого документа } & \\
\hline & \multicolumn{2}{|c|}{ дослідження взаємопов’язаних документів } & \\
\hline & \multicolumn{2}{|c|}{ аналіз облікових даних } & \\
\hline & \multicolumn{2}{|c|}{$\begin{array}{l}\text { оцінка законності й обгрунтованості господарських операцій за даними кореспо- } \\
\text { ндуючих рахунків бухгалтерського обліку і т. ін. }\end{array}$} & \\
\hline \multirow{7}{*}{ Органолептичні } & \multicolumn{2}{|c|}{$\begin{array}{l}\text { вибіркові спостереження - прийом статистичного дослідження якісних характе- } \\
\text { ристик об’єкта, коли суцільний контроль технічно неможливий (наприклад, для } \\
\text { визначення дефектів товарів, які надходять у торгівлю) }\end{array}$} & 恶 \\
\hline & \multicolumn{2}{|c|}{$\begin{array}{l}\text { суцільні (безперервні) спостереження (проведення хронометражних спостере- } \\
\text { жень під час експертизи норм виробітку) }\end{array}$} & 茯 \\
\hline & \multicolumn{2}{|c|}{$\begin{array}{l}\text { контрольні заміри робіт (для перевірки наявності виконаних будівельно- } \\
\text { монтажних робіт, обсягів виробництва, робіт і послуг) }\end{array}$} & 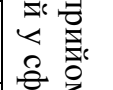 \\
\hline & \multicolumn{2}{|c|}{$\begin{array}{l}\text { технологічні експертизи - прийом контролю інженерної і технічної підготовки } \\
\text { виробництва, а також якості продукції (контрольний запуск сировини і матеріа- } \\
\text { лів у виробництво, який застосовується }\end{array}$} & 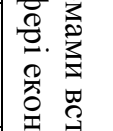 \\
\hline & \multicolumn{2}{|c|}{ для визначення обгрунтованості норм витрат матеріалів) } & 范 \\
\hline & \multicolumn{2}{|c|}{$\begin{array}{l}\text { службове розслідування - сукупність прийомів перевірки дотримання службо- } \\
\text { вими особами та іншими працівниками нормативно-правових актів, що регулю- } \\
\text { ють виробничі відносини }\end{array}$} & 를 \\
\hline & \multicolumn{2}{|c|}{$\begin{array}{l}\text { експеримент - науково організоване дослідження з метою експертної оцінки ре- } \\
\text { зультатів виконаних процесів }\end{array}$} & \\
\hline
\end{tabular}

* Узагальнено авторами на підставі аналізу джерел $[5 ; 6 ; 7 ; 8 ; 9]$ 
Документальна експертиза пов'язана із детальним вивченням інформації первинних документів, інших технічних та облікових документів, їхньою перехресною перевіркою та порівнянням із довідковими та науковими даними (табл. 3).

Методичні прийоми документального дослідження облікової інформації *

Таблиця 3

\begin{tabular}{|c|c|c|}
\hline Процедури дослідження & Мета дослідження & Зміст процедури \\
\hline \multicolumn{3}{|c|}{ 1.Прийоми дослідження окремого документа } \\
\hline $\begin{array}{l}\text { 1.1.Перевірка документа за } \\
\text { формою }\end{array}$ & \multirow{4}{*}{$\begin{array}{l}\text { Підтвердження закон- } \\
\text { ності та правильності } \\
\text { облікових документів та } \\
\text { виявлення недоброякіс- } \\
\text { них документів }\end{array}$} & $\begin{array}{l}\text { Встановлюється наявність всіх обов’язкових рек- } \\
\text { візитів }\end{array}$ \\
\hline 1.2.Арифметична перевірка & & $\begin{array}{l}\text { Встановлюється правильність підсумкових показ- } \\
\text { ників в документах }\end{array}$ \\
\hline $\begin{array}{l}\text { 1.3.Нормативно-правова } \\
\text { перевірка }\end{array}$ & & $\begin{array}{l}\text { Полягає в перевірці облікових операцій на відпо- } \\
\text { відність вимогам чинного законодавства та вста- } \\
\text { новленим нормативам }\end{array}$ \\
\hline 1.4.Логічний контроль & & $\begin{array}{l}\text { Полягає у логічному аналізі об’єктивної можливо- } \\
\text { сті виконання документально оформлених госпо- } \\
\text { дарських операцій }\end{array}$ \\
\hline \multicolumn{3}{|c|}{$\begin{array}{c}\text { 2.Прийоми дослідження кількох документів, які відображають одну й ту саму або взаємозв’язані } \\
\text { операції }\end{array}$} \\
\hline 2.1.Зустрічна перевірка & $\begin{array}{l}\text { Встановити тотожність } \\
\text { даних різних примірників. } \\
\text { встановлення можливих } \\
\text { розбіжностей між ними }\end{array}$ & $\begin{array}{l}\text { Полягає в порівнянні окремих примірників одного } \\
\text { й того самого документа, які перебувають у різних } \\
\text { організаціях, а також документів, пов'язаних між } \\
\text { собою однією операцією. }\end{array}$ \\
\hline $\begin{array}{l}\text { 2.2.Порівняння даних ана- } \\
\text { літичного обліку } 3 \text { даними } \\
\text { синтетичного обліку }\end{array}$ & $\begin{array}{l}\text { Встановлення можливих } \\
\text { розбіжностей між ними }\end{array}$ & $\begin{array}{l}\text { Зіставляються дані синтетичного та відповідного } \\
\text { аналітичного обліку }\end{array}$ \\
\hline $\begin{array}{l}\text { 2.3.Взаємний контроль (зіс- } \\
\text { тавлення документів) }\end{array}$ & $\begin{array}{l}\text { Встановити тотожність } \\
\text { облікових даних про } \\
\text { одну й ту саму опера- } \\
\text { цію, яка відбита в різних } \\
\text { документах, встанов- } \\
\text { лення можливих розбі- } \\
\text { жностей між ними }\end{array}$ & $\begin{array}{l}\text { зіставляються різні документи і облікові дані, в } \\
\text { яких прямо чи опосередковано відображається } \\
\text { операція, що перевіряється. Зіставлятися можуть } \\
\text { дані фінансового, управлінського й оперативного } \\
\text { обліку }\end{array}$ \\
\hline \multicolumn{3}{|c|}{$\begin{array}{l}\text { 3. Прийоми перевірки відображення господарських операцій } \\
\text { у бухгалтерському обліку }\end{array}$} \\
\hline $\begin{array}{l}\text { 3.1.Відновлення кількісно- } \\
\text { сумарного обліку }\end{array}$ & $\begin{array}{l}\text { Підтвердження кількос- } \\
\text { ті та вартості залишків } \\
\text { майна }\end{array}$ & $\begin{array}{l}\text { На підставі первинних документів повністю відно- } \\
\text { влюється кількісний облік }\end{array}$ \\
\hline $\begin{array}{l}\text { 3.2.Спосіб зворотного ра- } \\
\text { хунку }\end{array}$ & $\begin{array}{l}\text { Виявлення безпідстав- } \\
\text { них списувань виробни- } \\
\text { чих запасів }\end{array}$ & $\begin{array}{l}\text { Грунтується на попередній експертній оцінці ма- } \\
\text { теріальних витрат, з метою подальшого визначен- } \\
\text { ня (зворотним рахунком) величини безпідставних } \\
\text { списувань сировини та матеріалів на виробництво } \\
\text { окремих видів продукції }\end{array}$ \\
\hline $\begin{array}{l}\text { 3.3.Оцінка законності й } \\
\text { обгрунтованості господар- } \\
\text { ських операцій за даними } \\
\text { кореспондуючих рахунків } \\
\text { бухгалтерського обліку }\end{array}$ & $\begin{array}{l}\text { Виявлення фальсифіка- } \\
\text { ції облікових даних }\end{array}$ & $\begin{array}{l}\text { За даними кореспондуючих рахунків бухгалтерсь- } \\
\text { кого обліку виявляють нестандартні записи та не- } \\
\text { санкціоновані виправлення }\end{array}$ \\
\hline
\end{tabular}

Використання результатів незалежних експертиз в системі внутрішньогосподарського контролю обліково-аналітичної системи підприємства є протидією ймовірності фінансово-економічних злочинів.

Альтернативою послугам зовнішньої експертизи можуть бути створені підприємством експертні відділи (служби). Їх основними функціями можуть стати:

- розробка корпоративної політики призначення та реалізації результатів експертних досліджень;

- планування експертної діяльності; 

експертиз;

- розробка методичних прийомів проведення

- проведення заходів внутрішнього контролю шляхом експертного дослідження;
- реалізація результатів експертизи шляхом надання відповідних рекомендацій щодо прийняття управлінських рішень тощо.

Таблиця 4

Органолептичні прийоми ідентифікації господарських операцій*

\begin{tabular}{|c|c|}
\hline Групи прийомів & Зміст та мета використання \\
\hline 1.Контрольні заміри робіт & $\begin{array}{l}\text { застосовуються для перевірки наявності виконаних будівельно-монтажних робіт, } \\
\text { обсягів виробництва, робіт і послуг }\end{array}$ \\
\hline $\begin{array}{l}\text { 2.Суцільні (безперервні) } \\
\text { спостереження }\end{array}$ & $\begin{array}{l}\text { прийом статистичного контролю фактичного стану об’єкта (наприклад, проведення } \\
\text { хронометражних спостережень під час експертизи норм виробітку) }\end{array}$ \\
\hline $\begin{array}{l}\text { 3. Вибіркові спостере- } \\
\text { ження }\end{array}$ & $\begin{array}{l}\text { прийом статистичного дослідження якісних характеристик об’єкта, коли суцільний } \\
\text { контроль технічно неможливий (для визначення дефектів товарів, які надходять у } \\
\text { торгівлю) }\end{array}$ \\
\hline 4.Експеримент & дослідження результатів виконаних робіт \\
\hline $\begin{array}{l}\text { 5.Технологічні експерти- } \\
\text { зи }\end{array}$ & $\begin{array}{l}\text { прийом контролю інженерної і технічної підготовки виробництва, а також якості } \\
\text { продукції, що випускається (наприклад, контрольний запуск сировини і матеріалів у } \\
\text { виробництво, який застосовується для визначення обгрунтованості норм витрат ма- } \\
\text { теріальних ресурсів, і вихід готової продукції) }\end{array}$ \\
\hline $\begin{array}{l}\text { 6.Службове розсліду- } \\
\text { вання }\end{array}$ & $\begin{array}{l}\text { сукупність прийомів перевірки дотримання службовими особами та іншими праців- } \\
\text { никами нормативно-правових актів, що регулюють виробничі відносини }\end{array}$ \\
\hline
\end{tabular}

* Узагальнено авторами на підставі аналізу джерел $[15 ; 16]$

Висновки та перспективи подальших досліджень. Оскільки основні положення щодо методики судової експертизи та експертизи, що проводиться підприємством із залученням внутрішніх та зовнішніх спеціалістів є ідентичними, вважаємо за необхідне внесення змін та доповнень до норм діючого законодавства щодо ототожнення категорій «експерт» та «спеціаліст» в галузі проведення експертизи, в т.ч. судової. На наш погляд, це:

- зробить можливим визнання висновку спеціаліста у вузькій галузі знань доказом у карній або цивільній справі;

- підвищить доказовий статус висновку спеціаліста для інвесторів та керівництва підприємства.

Подальше вивчення питань організації експертної діяльності на підприємстві дозволить детальніше розглянути питання обліково-аналітичного забезпечення експертного дослідження та розробити організаційний механізм проведення внутрішніх експертиз.

\section{Література}

1. Ткачук Г.О. Принципи, задачі та структура обліково-аналітичної системи підприємства / Г.О.Ткачук // Науково-методичні аспекти обліково-аналітичної системи підприємства: [монографія] / [В.В. Немченко, Ф.А. Трішин, Л.В. Іванченкова, Н.М. Купріна, Г.О. Ткачук та ін.] ; за заг. ред. д. е. н., проф. В.В. Немченко. - Одеса: Фенікс, 2016. - С. 9-22.

2. Ткачук Г.О. Ідентифікація загроз внутрішнього середовища шляхом проведення експертизи / Г.О.Ткачук, О.В. Щукіна // Науково-методичні аспекти обліково-аналітичної системи підприємства: [монографія] / [В.В. Немченко, Ф.А. Трішин, Л.В. Іванченкова, Н.М. Купріна, Г.О. Ткачук та ін.] ; за заг. ред. д. е. н., проф. В.В. Немченко. - Одеса: Фенікс, 2016. - С.126-136

3. Про судову експертизу : за станом на 01.01.2016р. [Електронний ресурс] / Верховна Рада України. Закон від 25.02.1994p. № 4038-XII. - Режим доступу: http://zakon5.rada.gov.ua/laws/show/4038-12.

4. Інструкція про призначення та проведення судових експертиз та експертних досліджень : за станом на 31.07.2015p. [Електронний ресурс] / Міністерство юстиції України. - Наказ від 08.10.98p. № 53/5. - Режим доступу: http://zakon4.rada.gov.ua/laws/show/z0705-98/page.

5. Судово-бухгалтерська експертиза: [навч. посіб. для студ. спец. 7.050106 «Облік і аудит»] / За ред. д.е.н., проф. Ф.Ф. Бутинця. - Житомир: ПП «Рута», 2004. - 460 с.

6. Гуцаленко Л. В. Судово-бухгалтерська експертиза: [навч. посіб.] / [Гуцаленко Л.В., Михальчишина Л.Г., Сидорчук В.М., Пентюк І.К.]. - К.: Центр учбової літератури, 2011. - 352 с.

7. Фортинский С.П. Судебно-бухгалтерская експертиза / С.П. Фортинский. - М.: Государственное издательство юридической литературы, 1962. - 236 с. 
8. Ромашов А. Методы судебно-бухгалтерской экспертизы / А. Ромашов, А. Соколов // Некоторые проблемы судебной экспертизы. - М.: Юридическая литература, 1978. - 160 с. 2006. - 336 c.

9. Судебная экспертиза: [учеб. пособ.] / Д.А. Сорокотягина, И.Н.Сорокотягин. - Ростов н/Д.: Феникс,

10. Доник Н.Я. Судова бухгалтерія / Н.Я. Доник, Г.П. Доник. - К.: Центр учбової літератури, 2011. 208 c.

11. Рудницький В. С. Судово-бухгалтерська експертиза економічних правопорушень (опорні конспекти): [навч. посіб.] / В.С. Рудницький, Р.Ф. Бруханський, П.Я. Хомин. - К.: ВД «Професіонал», $2004 .-304$ с.

12. Іванченова Л.В. Методичні прийоми внутрішньогосподарського контролю та їх удосконалення / Л.В. Іванченкова, В.С. Іванченков // Науково-методичні аспекти обліково-аналітичної системи підприємства: [монографія] / [В.В. Немченко, Ф.А. Трішин, Л.В. Іванченкова, Н.М. Купріна, Г.О. Ткачук та ін.] ; за заг. ред. д. е. н., проф. В.В. Немченко. - Одеса: Фенікс, 2016. - С. 232-255.

13. Дмитренко Т.М. Судебная (правовая) бухгалтерия / Дмитренко Т.М., Чаадаев С.Г. - М.: «Проспект», 1998. - $336 \mathrm{c.}$

14. Дубоносов Е.С. Судебная бухгалтерия: [учебно-практ. пособие] / Е.С. Дубоносов. - М.: Книжный мир, 2006. - 252 с.

15. Волкова I. А. Судово-бухгалтерська експертиза: [навч. посіб. для студ. вищ. навч. закл.] / I. А. Волкова - К.: Центр учбової літератури, 2009. - 84 с.

16. Мумінова-Савіна Г.Г. Судово-бухгалтерська експертиза: [навч.-метод. посіб. для самост. вивч. дисципліни] / Г.Г. Мумінова-Савіна. - К.: КНЕУ, 2004. - 268 с.

Стаття надійшла 29.10.2016

Стаття прийнята до друку 13.11.2016 Доступно в мережі Internet 30.12.2016

\author{
Иванченкова Л.В. \\ кандидат экономических наук, доцент \\ E-mail: l.ivanchenkova@mail.ru \\ Ткачук Г.А. \\ кандидат экономических наук, доцент \\ E-mail: talla2007@ukr.net \\ Скляр Л.Б. \\ кандидат экономических наук, доцент \\ кафедра учета и аудита \\ Одесская национальная академия пищевых технологий \\ ул. Канатная, 112, г. Одеса, Украина, 65039 \\ E-mail: sklyarl@mail.ru
}

\title{
ЭКСПЕРТНОЕ ПОДТВЕРЖДЕНИЕ УЧЕТНО-АНАЛИТИЧЕСКОЙ ИНФОРМАЦИИ
}

Учетно-аналитическая информация должна быть защищена от возможных ошибок и искажений. Гарантом ее достоверности выступают меры внутреннего и внешнего контроля, включая экспертное подтверждение информации.

В данной статье выделены направления организации экспертных исследований на предприятии. Обобщена информация о видах экспертиз для идентификации финансово-экономических правонарушений с определением ожидаемого результата от экспертизы. Систематизированы методические приемы документального исследования учетной информации с определением цели исследования и содержания процедур, которые выполняются. Определено содержание и цель использования органолептических приемов идентификации хозяйственных операций. Выделены основные функции экспертной службы предприятия. Авторами сделаны выводы, что дальнейшее изучение предложенной тематики позволит подробно рассмотреть вопрос учетно-аналитического обеспечения экспертного исследования и разработать организационный механизм проведения внутренних экспертиз.

Ключевые слова: учетно-аналитическая информация, экспертиза, судебно-бухгалтерская экспертиза, методические приемы экспертизы, фринансовые правонарушения. 


\author{
Ivanchenkova L. \\ Ph.D. in Economics, Associate Professor \\ E-mail: I.ivanchenkova@mail.ru \\ Tkachuk G. \\ Ph.D. in Economics, Associate Professor \\ E-mail: talla2007@ukr.net \\ Sklyar L. \\ Ph.D. in Economics, Associate Professor \\ Department of Accounting and Auditing \\ Odessa National Academy of Food Technologies \\ Kanatna str., 112 , Odessa, Ukraine, 65039 \\ E-mail: sklyarl@mail.ru
}

\title{
EXPERT CONFIRMATION OF ACCOUNTING AND ANALYTICAL INFORMATION
}

Accounting and analytical information must be protected from possible errors and distortions. Guarantor of its of reliability are the measures of internal and external control, including expert confirmation of the information.

In this article highlights the direction of the organization of expert studies in the enterprise. Compiled information about the kinds of expertise for the identification of financial and economic offenses to the definition of the expected result of the examination. Are systematized instructional techniques of documentary research of accounting information with the definition of the research objectives and contents of the procedures are performed. The content and purpose of the use of of organoleptic methods of identification of economic operations. Identified the main function of the expert service of the enterprise. The authors concluded that further study of the proposed themes will allow detailed consideration of accounting and analytical support of the expert research and to develop an institutional mechanism conducting internal expert.

Keywords: accounting and analytical information, expertise, forensic accounting, instructional techniques of expertise, financial offenses.

\section{References}

1. Tkachuk H. O., Nemchenko, V. V., Trishyn, F. A., Ivanchenkova, L. V., \& Kuprina, N. M. (2016). Pryntsypy, zadachi ta struktura oblikovo-analitychnoi systemy pidpryiemstva. Naukovo-metodychni aspekty oblikovoanalitychnoi systemy pidpryiemstva, 9-22.

2. Tkachuk H. O., O.V. Shchukina, Nemchenko, V. V., Trishyn, F. A., Ivanchenkova, L. V., \& Kuprina, N. M. (2016). Identyfikatsiia zahroz vnutrishnoho seredovyshcha shliakhom provedennia ekspertyzy. Naukovometodychni aspekty oblikovo-analitychnoi systemy pidpryiemstva, 126-136.

3. Pro sudovu ekspertyzu : za stanom na 01.01.2016r. (2016, January 01). Retrieved October, 2016, from http://zakon5.rada.gov.ua/laws/show/4038-12.

4. Instruktsiia pro pryznachennia ta provedennia sudovykh ekspertyz ta ekspertnykh doslidzhen. (2015, July 31). Retrieved October, 2016, from http://zakon4.rada.gov.ua/laws/show/z0705-98/page.

5. Butyntsia, F. F. (2004). Sudovo-bukhhalterska ekspertyza. Zhytomyr: PP «Ruta».

6. Hutsalenko, L. V., Mykhalchyshyna, L. H., Sydorchuk, V. M., \& Pentiuk, I. K. (2011). Sudovobukhhalterska ekspertyza:. K.: Tsentr uchbovoi literatury.

7. Fortynskyi , S. P. (1962). Sudebno-bukhhalterskaia ekspertyza. M.: Hosudarstvennoe yzdatelstvo yurydycheskoi lyteraturы.

8. Romashov, A., \& Sokolov, A. (1978). Metodы sudebno-bukhhalterskoi эkspertyzы. Nekotorыe problemы sudebnoi эkspertyzы. M.

9. Sorokotiahyna, D. A., \& Sorokotiahyn, Y. N. ( 2006). Sudebnaia эkspertyza. Rostov n/D.: Fenyks.

10. Donyk, N. Ia., \& Donyk, H. P. (2011). Sudova bukhhalteriia. K.: Tsentr uchbovoi literatury.

11. Rudnytskyi, V. S., Brukhanskyi, R. F., \& Khomyn, P. I. (2004). Sudovo-bukhhalterska ekspertyza ekonomichnykh pravoporushen. K.: VD «Profesional».

12. Ivanchenova, L. V., \& Ivanchenkov, V. S., Nemchenko, V. V., Trishyn, F. A., Kuprina N. M. \& Tkachuk H. O. (2016). Pryntsypy, zadachi ta struktura oblikovo-analitychnoi systemy pidpryie (2016). Metodychni pryiomy vnutrishnohospodarskoho kontroliu ta yikh udoskonalennia . Naukovo-metodychni aspekty oblikovo-analitychnoi systemy pidpryiemstva, 232-255.

13. Dmytrenko, T. M., \& Chaadaev, S. H. (1998). Sudebnaia (pravovaia) bukhhalteryia . M.: «Prospekt».

14. Dubonosov , E. S. (2006). Sudebnaia bukhhalteryia. M.: Knyzhnыi myr.

15. Volkova, I. A. (2009). Sudovo-bukhhalterska ekspertyza. K.: Tsentr uchbovoi literatury.

16. Muminova-Savina, H. H. (2004). Sudovo-bukhhalterska ekspertyza. K.: KNEU. 